\title{
Esterhuizen en die gladde stiltes van die digkuns
}

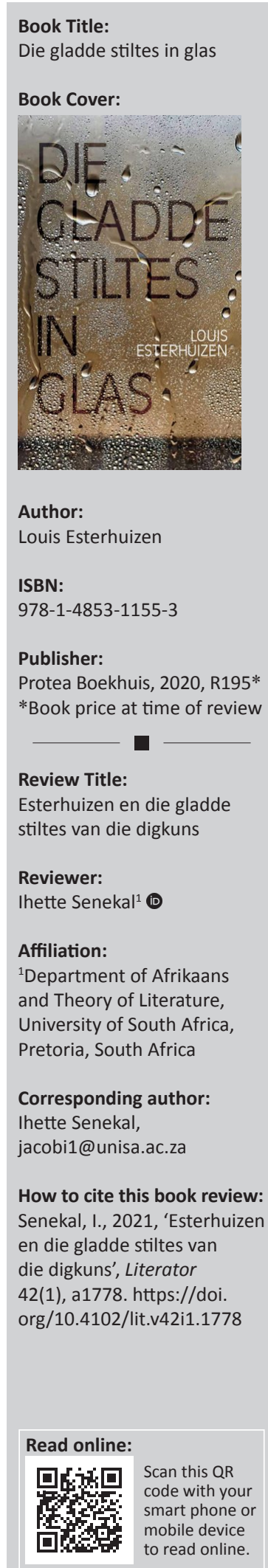

In die Afrikaanse poësiekringe het Louis Esterhuizen geen bekendstelling nodig nie. Die gladde stiltes in glas is reeds sy elfde digbundel en benewens hierdie gevestigde bundelaanbod, is sy verse ook opgeneem in vele versamelpublikasies. As aktivis vir die bevordering van die Afrikaanse poësie staan Esterhuizen se naam uit en is hy onder meer 'n stigterslid van die gewilde Versindaba.

Sy nuutste publikasie, Die gladde stiltes in glas, verskyn in 2020 by Protea Boekhuis. Die bundel is reeds hoog aangeskryf deur talle resensente en dit is by hierdie groep wat ek my in hierdie resensie wil skaar.

Op spirituele vlak, word die getal elf beskou as 'n weg tot verligting, en in dié opsig is dit veelseggend dat hierdie bundel dan juis Esterhuizen se elfde bundel is. Die bundel werk met glas as uitgebreide metafoor en sluit die motiewe van lig, vuur en suiwering in. Die talle ars poëtikale gedigte bied ook 'n verligtende blik op die manier hoe Esterhuizen die poësie beskou en uitbeeld in terme van hierdie metafore en motiewe.

Een van die uitstaande aspekte van die bundel is die poëtikale gesprek wat Esterhuizen aanknoop met N.P. van Wyk Louw en H.J. Pieterse. Die bundelmotto is geneem uit H.J. Pieterse se 'Liturgie van kristal' (Die burg van hertog Bloubaard, 2000) en is reeds 'n aanduiding van belangrike motiewe wat in die bundel figureer, naamlik mure, vensters, kristal (glas), vonk (vuur) en die verband tussen die hede en verlede. Hierdie motto is duidelik met sorg uitgekies en is verder vervleg deur die bundelinhoud in terme van die ooreenstemmende werkswyse van Pieterse in Die burg van hertog Bloubaard en Esterhuizen in Die gladde stiltes in glas. Net soos wat Pieterse in sy bundel van die burg gebruik maak as 'n uitgebreide metafoor wat laag vir laag opgebou word tot 'n veelvlakkige betekenisgenereerder, maak Esterhuizen op dieselfde wyse gebruik van die metafoor van glas.

Die intertekstuele gesprek wat Esterhuizen aanknoop met N.P. van Wyk Louw, is nie 'n eerste vir Esterhuizen se oeuvre nie en in Die gladde stiltes in glas sluit hierdie gesprek op 'n besonder vindingryke wyse aan by die poëtikale beskouings wat tot stand kom deur die gebruik van deurlopende metafore en motiewe. Die openingsgedig 'Eerste lig' (p. 11) herinner aan die openingsgedig van Van Wyk Louw se Tristia (1962), 'Voorspel 1950'. In beide gedigte word poëtikale insigte uitgebeeld deur die konsep van poëtiese 'vorm en inhoud' te verbind aan die idee van vloeistof geskink in glas. Van Wyk Louw stel 'Miskien sal ek die wingerd prys / en nooit meer van hom drink / en net in 'n verbeelde glas / die koel gedagte skink'. Esterhuizen se weergawe lui weer: 'die glas water op die vensterbank / is begeerte se uitbeelding / van 'n samespel tussen vorm en inhoud'. Dié intertekstuele verband word uitgebrei deur poësie as 'n proses van suiwering te sien. Van Wyk Louw beeld dié gedagte in 'Voorspel 1950' uit as die suiweringsproses waardeur wyn gaan en Esterhuizen gebruik weer die metafoor van vuur wat glas vorm - 'Die glas onthou immers die vuur'. Esterhuizen hervat die metafoor van die vorming van glas as verteenwoordigend van die skep van poësie in 'Die glasblaser' (p. 19). 'Eerste lig' eggo ook die bundelmotto geleen uit Pieterse se poësie, en vervleg uit die staanspoor die stemme van Pieterse, Van Wyk Louw en Esterhuizen. Hierdie strategie laat die poësieliefhebber gretig omblaai om Die gladde stiltes in glas verder te verken.

Die openingsgedig is egter nie waar die gesprek met Van Wyk Louw eindig nie. Vele gedigte in die bundel hervat en verryk hierdie gesprek tot ' $n$ betekenisrykdom. So byvoorbeeld is daar weer 'n poëtikale ooreenkoms tussen Esterhuizen se 'Ars poëtika' (p. 34) en Van Wyk Louw se 'Ex unguine leonem' (Tristia). Beide gedigte suggereer dat die poësie 'n poging is om verganklikheid te besweer, maar dat die mens slegs in staat is om, volgens Esterhuizen, 'n gedig

Copyright: @ 2021. The Authors. Licensee: AOSIS. This work is licensed under the Creative Commons Attribution License. 
te skryf 'in sand', en volgens Van Wyk Louw skryf die mens 'na in stof'. Ander verwysings na Van Wyk Louw sluit in 'Piekniek op Clifton' (p. 42) en 'Drieluik' (p. 54). Laasgenoemde se subtitel lui 'Van Wyk Louw, vyftig jaar later', en verwys na Die gladde stiltes in glas wat vyftig jaar na Van Wyk Louw se dood verskyn.

Die gladde stiltes in glas bestaan uit drie afdelings, naamlik 'Steierwerk', 'Buiteligmusiek' en 'Grondwaarts'. Die afdelingtitels is veelseggend in terme van die bundelinhoud. In 'Restourasie' (p. 15) word die poëtikale suggestie wat deur die bundel loop, verwoord as 'om die gedig te vestig / as steierwerk teen ' $n$ stadige verkrummeling'. Die tweede afdelingtitel dui op die verbande wat tussen die bundel en musikale intertekste gelê word. Hierdie afdeling word genoem "n Komposisie met tema en variasie in veertig bewegings' en verskil van die res van die bundel in vorm en aanbieding. Dit is ook die afdeling waarin van die mooiste liefdesgedigte van die bundel vervat word, en waar die belang van 'n muse uitgewys word. Die motto van die afdeling is geleen uit 'n onderhoud met Arvo Pärt en kom daarop neer dat musiek 'n luisteraar benodig om dit oop te sluit. Op dieselfde wyse benodig poësie dan 'n leser, maar ook'n muse, want die geliefde kan as muse omskep word tot poësie: 'wanneer sy langs jou kom lê, / onder jou hand taal word' (p. 75). Die derde afdelingtitel wys op die deurlopende motiewe van swaartekrag, vertigo en die tema van die dood. In talle gedigte word na die dood van familielede verwys en telkens verbind met die idee om grondwaarts te keer, soos byvoorbeeld in 'Elegie by die afreis' (p. 101).

Die gladde stiltes in glas is ' $\mathrm{n}$ bundel met talle hoogtepunte en 'n ryk en gelaagde bundelinhoud. Die gedig 'Toe was die wind daar en sê ...' (p. 33) kan gesien word as 'n sleutelgedig in terme van die filosofiese onderbou van hierdie bundel: Daar kan slegs gepoog word om oerbegrippe soos tyd, dood, begeerte en melankolie vas te vang in woord (die gedig) soos water in 'n holte of ' $n$ glas, maar dit kan nooit werklik afgebaken word deur 'n mens se hand wat slegs in sand en stof kan (na-)skryf nie. 